\title{
Cholesterol metabolism in innate and adaptive response
}

\section{[version 1; peer review: 2 approved]}

\author{
Andrea Reboldi(iD1, Eric Dang 2 \\ ${ }^{1}$ Department of Pathology, University of Massachussetts Medical School, Worcester, Massachusetts, 01605, USA \\ ${ }^{2}$ Department of Biochemistry and Biophysics, University of California, San Francisco, California, 94158, USA
}

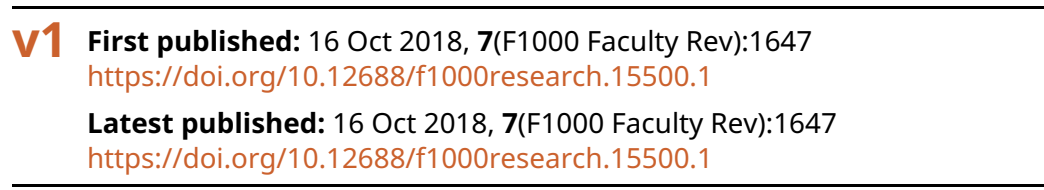

\section{Abstract}

It has been long recognized that cholesterol is a critical molecule in mammalian cell biology, primarily for its contribution to the plasma membrane's composition and its role in assuring proper transmembrane receptor signaling as part of lipid rafts. Efforts have also been made to characterize the cholesterol biosynthetic pathway, cholesterol homeostasis, and cholesterol-derived metabolites in order to gain insights into their dysregulation during metabolic diseases. Despite the central role cholesterol metabolism plays in shaping human health, its regulation during immune activation, such as immune response to pathogens or autoimmune/autoinflammatory diseases, is poorly understood.

The immune system is composed of several type of cells with distinct developmental origin, life span, molecular requirements, and gene expressions. It is unclear whether the same array of cholesterol metabolism regulators are equally employed by different immune cells and whether distinct cholesterol metabolites have similar biological consequences in different immune cells.

In this review, we will describe how cholesterol metabolism is controlled during the adaptive and the innate immune response and the role for intracellular and extracellular receptors for cholesterol and its derivatives.

\section{Keywords}

cholesterol, liver $x$ receptor, sterol response element-binding proteins

\section{Open Peer Review}

Approval Status

1 2

version 1

16 Oct 2018

Faculty Reviews are review articles written by the prestigious Members of Faculty Opinions. The articles are commissioned and peer reviewed before publication to ensure that the final, published version is comprehensive and accessible. The reviewers who approved the final version are listed with their names and affiliations.

1. John Chiang (D), Northeast Ohio Medical University, Rootstown, USA

2. Michael Fessler, National Institutes of Health, Research Triangle Park, USA Any comments on the article can be found at the end of the article. 
Corresponding authors: Andrea Reboldi (Andrea.Reboldi@umassmed.edu), Eric Dang (Eric.Dang@ucsf.edu)

Author roles: Reboldi A: Writing - Original Draft Preparation, Writing - Review \& Editing; Dang E: Writing - Original Draft Preparation, Writing - Review \& Editing

Competing interests: No competing interests were disclosed.

Grant information: This work was supported by the Jane Coffin Child's Memorial Fellowship (EVD), the Kenneth Rainin Foundation (AR), and the Charles H. Hood Foundation (AR).

The funders had no role in study design, data collection and analysis, decision to publish, or preparation of the manuscript.

Copyright: $\odot 2018$ Reboldi A and Dang E. This is an open access article distributed under the terms of the Creative Commons Attribution License, which permits unrestricted use, distribution, and reproduction in any medium, provided the original work is properly cited.

How to cite this article: Reboldi $A$ and Dang E. Cholesterol metabolism in innate and adaptive response [version 1; peer review: 2 approved] F1000Research 2018, 7(F1000 Faculty Rev):1647 https://doi.org/10.12688/f1000research.15500.1

First published: 16 Oct 2018, 7(F1000 Faculty Rev):1647 https://doi.org/10.12688/f1000research.15500.1 


\section{Introduction}

Cholesterol has a central and ubiquitous role in mammalian cells, as the pathway of cholesterol biosynthesis from acetyl coenzyme $\mathrm{A}$ is active in all nucleated cells and cholesterol is an essential component of mammalian plasma membrane, accounting for up to $25 \%$ of all membrane lipid. The cholesterol structure confers rigidity to the plasma membrane; thus, a different percentage of cholesterol results in different plasma membrane rigidity. Several biological processes are controlled by cholesterol-containing lipid rafts on the plasma membrane, including transmembrane receptor signaling and virus entry and budding ${ }^{1}$.

Despite the critical role for cholesterol in mammalian membrane homeostasis, excess cellular cholesterol is toxic and therefore cholesterol biosynthesis requires tight regulation. Cholesterol has been recognized to exert a negative feedback loop on its own biosynthesis and uptake, and its metabolism has been extremely well characterized molecularly. Although virtually all mammalian cells are dependent on cholesterol metabolism, there is a limited understanding of how cholesterol metabolism is regulated in the steady state and during immune activation, such as in response to infection and during autoimmunity.

Dissecting how cholesterol shapes the immune response is complicated by the multilayered, complex role of cholesterol: in addition to having its own effects on cellular homeostasis, cholesterol is the substrate for the production of several metabolites, including oxysterols ${ }^{2}$, bile acids $^{3}$, and steroid hormones ${ }^{4}$. These cholesterol-derived metabolites have diverse immunomodulatory as well as metabolic effects; the intracellular and extracellular receptors for cholesterol and its derivatives have not been completely characterized in every immune cell type; and the potentially different impact of cholesterol origin (dietary or endogenous) on immune activation has not been fully understood. In this review, we will describe the main regulators of cholesterol metabolism and their role in the adaptive and the innate immune response.

\section{SREBP}

Groundbreaking work from Goldstein et al. defined cholesterol as a key molecule in suppressing its own biosynthesis through a negative feedback circuit ${ }^{5}$. Cholesterol exerts its function by preventing sterol response element-binding proteins (SREBPs) from promoting sterol biosynthesis. SREBPs are transcription factors that promote the transcription of enzymes in the cholesterol biosynthetic pathway, including 3-hydroxy-3methylglutaryl-CoA reductase (HMGCR), as well as the lowdensity lipoprotein (LDL) receptor, which is responsible for cholesterol uptake ${ }^{6}$. In the presence of cholesterol, SREBPs are kept in the endoplasmic reticulum (ER) by the multitransmembrane SREBP cleavage-activating protein (SCAP) which binds the ER-resident insulin-induced gene (INSIG) ${ }^{7}$. SCAP contains a sterol-sensing domain that is thought to bind ER membrane cholesterol ${ }^{8}$; when cholesterol levels drop in the ER, SCAP detaches from INSIG through a conformational change? ${ }^{9}$ SCAP then escorts SREBPs into the Golgi, where site 1 and site 2 proteases cleave SREBPs and activate them as transcription factors ${ }^{10}$. SREBP family members include three proteins: SREBP1a, SREBP1c, and SREBP2 ${ }^{11}$.

SREBP2 is encoded by the Srebf2 gene, whereas SREBP-1a and SREBP-1c both are encoded by the Srebfl gene: SREBP-1a and SREBP-1c are different isoforms of SREBP1 that arise from alternate promoter usage. Despite their similar regulation, SREBP proteins have a distinct effect on cellular lipid metabolism. SREBP1c controls the transcription of genes involved in the biosynthesis of fatty acids; SREBP2 controls the transcription of genes involved in cholesterol biosynthesis, intracellular lipid movement, and lipoprotein import, whereas the SREBP1a transcriptional regulon partially overlaps with that of SREBP1c and SREBP2.

\section{LXR}

The liver $X$ receptor alpha $(L X R \alpha)$ and beta $(L X R \beta)$ are members of the nuclear hormone receptor family of transcription factors that have key roles in regulating the homeostasis of cholesterol and fatty acids. LXR $\alpha$ and LXR $\beta$ have distinct patterns of expression; LXR $\beta$ is ubiquitously expressed across most cell types, whereas $\mathrm{LXR} \alpha$ is restricted mainly to adipose tissue, the liver, and the intestine.

LXRs control intracellular levels of cholesterol by transcribing genes that encode proteins involved in sterol efflux, such as Abcal, Abcgl, and Apoe, therefore preventing cholesterol accumulation. LXRs also induce the expression of SREBP1c and enzymes involved in fatty acid remodeling, such as Elovl5, Fads2, Scd1, and $S c d 2$. As LXRs are thought to work in a ligand-dependent manner, several efforts have been made to define the endogenous ligands for LXRs, but so far the identity of native ligands that activate LXRs in vivo has remained elusive.

\section{Oxysterols}

Cholesterol can be enzymatically modified to form metabolites with diverse bioactivities ${ }^{3}$. The most characterized proximal cholesterol metabolites are oxysterols, which are oxidized via hydroxylation reactions typically on the non-cyclic side chain of cholesterol. 25-hydroxycholesterol (25-HC) is synthesized from cholesterol by the addition of a hydroxyl group at position 25: the enzyme responsible for 25-hydroxylation reaction is cholesterol 25-hydroxylase $(\mathrm{CH} 25 \mathrm{H})$, a multi-transmembrane ER protein. 27-HC is instead generated through the action of the sterol 27-hydroxylase CYP27A1, a mitochondrial cytochrome $\mathrm{P} 450$ oxidase. Both $25-\mathrm{HC}$ and $27-\mathrm{HC}$ can be hydroxylated at the $7 \alpha$ position by the enzyme $7 \alpha$-hydroxylase (CYP7B1) to generate $7 \alpha, 25-\mathrm{HC}$ and $7 \alpha, 27-\mathrm{HC}$. CYP7B1 is a cytochrome $\mathrm{P} 450$ family enzyme and is also situated in the ER. Both CYP7B1 and CYP27A1 are abundant in the liver, whereas $\mathrm{CH} 25 \mathrm{H}$ is virtually absent in the liver under homeostatic conditions. This is in line with the described role of CYP27A1 and $\mathrm{CYP} 7 \mathrm{~B} 1$, but not $\mathrm{CH} 25 \mathrm{H}$, in the conversion of cholesterol into bile acids, making several oxysterols de facto bile acid synthesis intermediates. Interestingly, all three enzymes can be found, albeit with a range of expression, in several other tissues. These include primary and secondary lymphoid organs, suggesting that they might play a role in a distinct set of 
biological processes, particularly immune regulation. Similar to other $7 \alpha$-hydroxylated sterols, $7 \alpha, 25-\mathrm{HC}$ and $7 \alpha, 27-\mathrm{HC}$ are metabolized by the enzyme $3 \beta$-hydroxysteroid dehydrogenase type 7 (HSD3B7), which is situated in the ER. HSD3B7, similar to CYP7B1 and CYP27A1, is very abundant in the liver and it is essential for bile acid synthesis; nevertheless, its ability to metabolize $7 \alpha, 25-\mathrm{HC}$ and its expression in other tissues suggest that it has an extrahepatic role in controlling oxysterol levels.

\section{Regulation of the SREBP pathway in macrophages}

Studies from the 1970s found that the addition of 25-HC to mitogen-stimulated lymphocyte cultures could repress proliferation $^{12}$. Intriguingly, the inhibited lymphocyte proliferation in the presence of $25-\mathrm{HC}$ could be rescued by cholesterol, suggesting that 25-HC could repress cholesterol biosynthesis. This phenomenon was subsequently explained by studies demonstrating that 25-HC can inhibit SREBP activation via direct binding to Insig- $1^{9}$. This causes Insig-1 to associate with the SCAP/SREBP complex and trap it in the ER. These data suggest that there are two layers of feedback regulation for the SREBP pathway: cholesterol-based feedback and oxysterolbased feedback.

Despite ample biochemical evidence that $25-\mathrm{HC}$ is a potent inhibitor of SREBP, the role of oxysterols in controlling cholesterol biosynthesis has been controversial. Initial analysis of Ch25h-knockout mice, which are thus 25-HC-deficient, found no evidence of homeostatic cholesterol abnormalities ${ }^{3}$. This suggested that perhaps endogenous $25-\mathrm{HC}$ plays a non-essential or redundant role in restricting SREBP activity. However, it is important to consider that levels of homeostatic cholesterol, particularly serum LDL and high-density lipoprotein (HDL), are controlled predominantly by hepatic lipoprotein metabolism. As described above, hepatic $C h 25 h$ expression levels are very low at baseline and this likely explains the lack of a genetic requirement for $\mathrm{Ch} 25 \mathrm{~h}$ in controlling whole animal cholesterol metabolism.

It is now appreciated that $\mathrm{Ch} 25 \mathrm{~h}$ is a type I interferon (IFN-I)-inducible enzyme, particularly in myeloid cells ${ }^{3-5}$. This is consistent with previous studies showing that IFN-I causes repression of cholesterol biosynthesis ${ }^{13}$. However, Blanc et al. and Liu et al. found that while $\mathrm{Ch} 25 \mathrm{~h} / 25-\mathrm{HC}$ has antiviral activity downstream of IFN-I signaling, this was uncoupled from its ability to inhibit the SREBP pathway, as expression of the constitutively active nuclear form of SREBP2 could not rescue the antiviral activity ${ }^{13,14}$. The authors proposed distinct models to explain the antiviral action of $25-\mathrm{HC}$. Liu et al. found that $25-\mathrm{HC}$ inhibits the entry of viruses into cells, potentially through remodeling of the host cell plasma membrane to prevent viral particle fusion. On the other hand, Blanc et al. suggested that $25-\mathrm{HC}$ blocks viral replication through inhibition of isoprenoid biosynthesis, as the addition of geranylgeraniol to 25-HC-treated cells could rescue viral titers. Recently, Bensinger et al. uncovered an additional co-regulation between IFN-I and cholesterol, as they showed that limiting the pool size of cholesterol synthesis induces type I IFN response in a
STING (stimulator of type I IFN genes)-dependent manner and protects them from viral infection ${ }^{15}$. Similarly, Ghazal et al. showed that an IFN-induced microRNA (miRNA), miR-342-5p, targets mevalonate-sterol biosynthesis through multiple mechanisms suppressing the pathway at different functional levels, further underlining the importance of IFN-I-cholesterol biosynthetic cross-talk in antiviral response ${ }^{16}$.

While the studies on IFN-I induction of $\mathrm{Ch} 25 \mathrm{~h}$ in the context of viral infection did point to a physiological role of oxysterols in controlling cholesterol metabolism, Reboldi et al. demonstrated for the first time that endogenous 25-HC controls SREBP activity in the context of inflammation ${ }^{17}$. The authors found that Ch25h knockout mice have increased interleukin-17A (IL-17A) production from $\alpha \beta$ and $\gamma \delta \mathrm{T}$ cells in secondary lymphoid organs. Additionally, bone marrow-derived macrophages (BMDMs) from Ch25h-knockout mice have augmented transcription and secretion of the cytokine IL-1 $\beta$, a potent inducer of IL-17A from lymphocytes, in response to lipopolysaccharide (LPS). Importantly, transcriptome analysis revealed that while unstimulated Ch25h-knockout BMDMs have no difference in SREBP pathway activity compared with wildtype cells, Ch25h-deficient BMDMs show hyper-SREBP activity upon LPS stimulation. Overexpression of Insig-1 and deletion of SCAP both decreased Illb mRNA levels, suggesting that SREBP can promote Illb transcription either directly or indirectly.

IL-1 $\beta$ and its family member IL-18 are unique among cytokines in that they lack a leader sequence for canonical protein secretion $^{18}$. Instead, IL-1 $\beta$ and IL-18 normally exist as cytosolic pro-form cytokines that must be cleaved for activation and cellular release. Activation of these cytokines is regulated by a multimeric protein complex known as "the inflammasome", which consists of an NLR/ALR family sensor protein, an adaptor protein called ASC, and the cysteine protease caspase- 1 . Ligand binding to an inflammasome sensor protein causes ATPdependent oligomerization and recruitment of ASC through PYRIN domain interactions. ASC then recruits caspase-1 via binding of their respective CARD domains. Because this complex is oligomeric, multiple caspase-1 proteins are brought into close proximity, which promotes caspase- 1 autoproteolysis and release of its active form that subsequently can process IL-1 $\beta$ and IL-18.

Since Ch25h-deficient BMDMs hyper-secrete IL-1 $\beta$ in response to LPS, this leads to the question of how the SREBP pathway and cholesterol pathway connect with inflammasome activation. Dang et al. found that dysregulation of macrophage cholesterol biosynthesis is sufficient to promote inflammasome activation and IL- $1 \beta$ processing ${ }^{19}$. Surprisingly, this seems to be downstream of the AIM2 inflammasome sensor protein, which canonically recognizes cytosolic double-stranded DNA (dsDNA). The authors found that dysregulated cholesterol biosynthesis in Ch25h-deficient BMDMs can cause mitochondrial damage, leading to release of mitochondrial DNA into the cytosol, thus providing a spurious ligand for AIM2. Additionally, NLRP3 was found to play a partially redundant role in driving 
inflammasome activation in response to cholesterol. This is consistent with studies showing that macrophage cholesterol accumulation in Abca1/Abcg1 double-knockout mice causes NLRP3 activation ${ }^{20}$.

\section{Liver $\mathrm{X}$ receptors control macrophage inflammatory signaling}

As described above, LXRs are key transcriptional regulators of cholesterol efflux in response to sterol overload. However, like SREBPs, LXRs are appreciated to have additional roles in controlling macrophage inflammation. Transcriptional studies found that the addition of the synthetic LXR agonist GW3965 to BMDMs could repress the expression of nuclear factor-kappa $\mathrm{B}$ $(\mathrm{NF}-\kappa \mathrm{B})$ target genes in response to LPS treatment ${ }^{21}$. This was shown to be dependent on LXRs, as LXR $\alpha \beta$ double-knockout macrophages were no longer responsive to GW3965, clearly demonstrating that LXR has the capacity to inhibit inflammation. Less clear is whether inflammatory/anti-inflammatory signals promote the expression of endogenous LXR agonists in macrophages, as most of the functional studies looking at the role of LXRs in inflammation have relied on the use of synthetic agonists.

The mechanism underlying LXR-dependent suppression of inflammatory signaling is also open to debate. Current evidence suggests that ligand binding promotes LXR SUMOylation, which causes LXR to target gene promoters for Toll-like receptor (TLR) target genes ${ }^{22}$. NCoR co-repressor complexes need to be removed from gene promoters in order for transcriptional activation to occur. This removal requires a member of the NCoR complex known as Coronin 2A, which binds to nuclear actin and thus promotes actin-dependent removal of NCoR from gene promoters ${ }^{23}$. It has been shown that SUMOylated LXR prevents turnover of NCoR complexes from TLR target gene promoters by interfering with Coronin $2 \mathrm{~A}$ binding to nuclear $\operatorname{actin}^{23}$. These data suggest a direct inhibition model for LXR repression of inflammatory gene induction, whereby binding to specific gene promoters prevents their transcription. However, a study by Ito et al. suggested that LXR primarily inhibits inflammatory signaling via its ability to promote Abca1/Abcg1dependent cholesterol efflux ${ }^{24}$. The authors found that GW3965 is no longer capable of suppressing TLR target gene transcription in Abca1-knockout macrophages that are impaired for efficient cholesterol efflux. The authors argue that the promotion of cholesterol efflux by LXR prevents the recruitment of MyD88 and TRAF6 to TLR signaling clusters on the plasma membrane ${ }^{24}$. Rong et al. additionally found that treatment of macrophages with GW3965 promotes the transcription of Lpcat3 in an LXRdependent manner ${ }^{25}$. Lpcat3 is a phospholipid (PL) remodeling enzyme that preferentially incorporates polyunsaturated fatty acids into PLs. The authors showed that knockdown of Lpcat3 induces ER stress and activation of NF- $\mathrm{KB}$-dependent cytokines in response to saturated fatty acid challenge. These data suggest that an additionally anti-inflammatory mechanism for LXR is preventing ER stress via induction of Lpcat3. The studies by Ito et al. and Rong et al. challenge the concept that LXR has direct repressor activity on inflammatory genes. Resolution of these conflicting models will require better reagents to assess genome-wide LXR target binding, as it would be of interest to determine whether Abcal deficiency affects LXR target choice.

Despite its described role in repressing inflammatory gene induction, LXR has also been described to be required for host survival of intracellular bacterial infection. LXR $\alpha \beta$ doubleknockout mice are more susceptible to Listeria monocytogenes infection, by both survival and colony-forming unit (CFU) analysis $^{26}$. This was initially argued to be a result of LXRdependent control of macrophage survival, as LXR-deficient BMDMs were more apoptotic when challenged with bacteria, potentially due to decreased expression of SP $\alpha$. However, these interpretations are complicated by recent data showing that LXR $\alpha$ is critical for development and maintenance of liver and splenic tissue macrophage populations ${ }^{27}$. LXR $\alpha$-knockout mice have dramatically decreased homeostatic numbers of Kupffer cells and splenic marginal zone macrophages, which could be a simple explanation for why these mice are susceptible to bacterial infections with a predilection for those organs. It is not clear whether LXR $\alpha$ promotes the differentiation or survival of liver and spleen macrophage populations. It is tempting to speculate that these macrophages are constantly being loaded with cholesterol because of phagocytosis of red blood cells and other circulating apoptotic cells and thus that the requirement for $\mathrm{LXR} \alpha$ reflects an adaptation to tissue-specific metabolic stress.

\section{Cholesterol metabolism in T-cell and B-cell proliferation}

The role of cholesterol in adaptive immune response was originally investigated in the context of lipid raft and antigen receptor signaling. Lipid rafts are plasma membrane microdomains with distinct lipid composition from the surrounding membrane, as they are enriched in cholesterol as well as in glycosphingolipids and sphingomyelin. Lipid rafts are stabilized by the addition of cholesterol, suggesting that intracellular cholesterol metabolism could control raft formation. Historically, the investigation of cholesterol significance in lipid raft during adaptive cell activation relied on chemical compounds, such as methyl $\beta$-cyclodextrin, to deplete cholesterol from the membrane raft and then assess B-cell receptor (BCR) and T-cell receptor (TCR) signaling ${ }^{28,29}$. However, these molecules often have a global effect on the plasma membrane and actin cytoskeleton, preventing us from drawing a conclusion about the role of cholesterol in the lipid raft. Most recently, the role of cholesterol and its metabolism in TCR signaling has been addressed in a more mechanistic way. For example, $\mathrm{Xu}$ et al. showed that inhibiting cholesterol esterification in T cells by genetic ablation or pharmacological inhibition of ACAT1, a key cholesterol esterification enzyme, potentiates $\mathrm{CD}^{+} \mathrm{T}$-cell effector function against tumors ${ }^{30}$. This effect was due to augmented plasma membrane cholesterol content that led to increased TCR clustering and immunological synapse formation ${ }^{30}$. The central role of cholesterol metabolism in controlling TCR signaling has also been highlighted by the findings of Davis et al., who showed that cholesterol sulfate, a naturally occurring analog of cholesterol, acts as a negative regulator of TCR signaling by disrupting TCR nanoclusters ${ }^{31}$. 
Upon antigen receptor stimulation, $\mathrm{T}$ cells and $\mathrm{B}$ cells activate a proliferative program that requires cell enlargement, organelle biogenesis, and cellular replication: in order to sustain the increased metabolic demands, anabolic pathways must be turned on, and they dominate the cellular metabolism ${ }^{32}$. The first evidence that cholesterol metabolism was critical for lymphocyte activation came from experiments taking advantage of statins, drugs that block HMG-CoA reductase, the enzyme responsible for catalysis in the rate-limiting step of cholesterol biosynthesis. $\mathrm{T}$ cells activated in vitro and treated with statin showed impaired proliferation ${ }^{33} ; \mathrm{B}$ cells showed a similar sensitivity to statin, but they strongly upregulate enzymes involved in the cholesterol biosynthetic activation upon CD40-CD40L interaction, the second signal in B-cell activation that has different kinetics and anatomic requirements in comparison with the BCR ligation ${ }^{34}$. The statin inhibitor effect is related to the cholesterol biosynthetic pathway but might not be directly dependent on the intracellular cholesterol levels. To fully characterize the role of cholesterol metabolism, new genetic and biochemical tools that allow a restricted and timely inhibition of distinct protein in the cholesterol pathway will be needed.

One critical observation of the central role for cholesterol metabolism during $\mathrm{T}$-cell and B-cell proliferation came from the age-dependent expansion of $\mathrm{T}$ cells and $\mathrm{B}$ cells in mice deficient in both $\operatorname{LXR} \alpha$ and $\operatorname{LXR} \beta^{35}$. Bensinger et al. suggested that oxysterols, not cholesterol per se, were acting as ligands for LXRs, as the addition of exogenous oxysterol activated LXRs in lymphocytes and blocked proliferation in an LXR-dependent fashion.

This observation was in line with the nature of several ligands of other nuclear hormone receptors, which are often small lipophilic molecules, and with the strong upregulation of the enzyme SULT2B1 upon T-cell activation. As SULT2B1 metabolizes oxysterols, it reduces oxysterol intracellular concentration and therefore their availability as LXR ligands.

The decreased signaling through LXR during T-cell activation was accompanied by a concomitant activation of SRBEP pathways, as SREBP-2 and SREBP1 target genes were strongly induced. More recently, it has been shown that, in $\mathrm{CD}^{+} \mathrm{T}$ cells, both SREBP1a and SREBP2 directly control cell growth and proliferation by mediating the lipid-anabolic program ${ }^{36}$. T cells lacking SREBP chaperone SCAP showed impaired proliferation and reduced cell enlargement because of a block in $G_{0}-G_{1}$. Pathway analysis suggested that SREBPs specifically regulated lipid anabolism and growth of $\mathrm{T}$ cells without perturbing TCR signaling or influencing other aspects of T-cell activation.

The described model that places LXR and SREBPs as central players during lymphocyte activation through the intracellular level of cholesterol and oxysterol does not completely recapitulate the in vivo observations. For example, although SCAP is critical in inhibiting SREBP activity in T cells and in influencing $\mathrm{CD}^{+}$proliferation in vitro, deletion of SCAP in vivo does not affect T-cell homeostasis, suggesting the possibility that other pathways are involved in controlling T-cell activation and play a more central role. Lymphocyte proliferation in vitro can be reduced in an LXR-dependent way with exogenous oxysterol treatment; nevertheless, mice deficient in the enzymes required for the generation of LXR-activating oxysterols did not show lymphocyte expansion. These discrepancies could have several non-mutually exclusive explanations: it is possible that in vivo different oxysterols play a redundant role in controlling lymphocytes through LXR; thus, only concomitant ablation of several enzymes would recapitulate the phenotype observed in LXR-deficient mice. It is also conceivable that other ligands for LXRs exist in vivo and that they are not cholesterol derivatives.

\section{Oxysterols control immune cell migration}

Despite the inconclusive data on the role of oxysterols in regulating T-cell and B-cell activation in vivo through SREBPs and LXR in vivo, more robust evidence exists for the oxysterols as migratory cues that shape the adaptive immune response ${ }^{37}$. In the effort to identify the ligand for the orphan receptor EBI2, two oxysterols-7 $-7,25-\mathrm{HC}$ and $7 \alpha, 27-\mathrm{HC}$-were identified as EBI2 ligands ${ }^{38} .25-\mathrm{HC}$ and $27-\mathrm{HC}$, which lack a single hydroxyl group and thus are intermediates in the enzymatic reaction that produces $7 \alpha, 25-\mathrm{HC}$ and $7 \alpha, 27-\mathrm{HC}$, are not able to activate EBI2. EBI2 is expressed by several immune cells but is especially high in B cells and is rapidly upregulated upon BCR stimulation. B cells rely on EBI2 to reach the outer follicles shortly after antigen engagement and then use both CCR7 and EBI2 to position at the T-B border and finally in the interfollicular regions and the outer follicle ${ }^{39}$. B cells deficient in EBI2 failed to properly migrate in the required microanatomic location of lymphoid organs and show reduced $\mathrm{T}$ cell-dependent antibody responses ${ }^{40,41}$. Genetic manipulation of the enzymes involved in the generation of EBI2 ligands reduced in vivo production of $7 \alpha, 25-\mathrm{HC}$ and $7 \alpha, 27-\mathrm{HC}$ and phenocopied the EBI2-deficient mice ${ }^{42}$. In addition to controlling B cells, EBI2 ligands control the positioning of a variety of immune cells in vivo: $\mathrm{T}$ follicular helper cells $\mathrm{s}^{43,44}$, ILC $3^{45,46}$, and dendritic cells ${ }^{47,48}$. In vivo, the location of the enzymes required for EBI2 ligand gradient generation has been characterized at least in the spleen, and both hematopoietic and non-hematopoietic cells have been shown to be involved in EBI2 ligand generation ${ }^{42}$. Ch25h transcript is abundantly found in the outer follicle and within interfollicular regions, including in the marginal zone bridging channel, but is low in B-cell follicles and the T-cell zone. In contrast, Cyp27a1 transcript is abundant in marginal zone bridging channels as well as in the T-cell zone but low in B-cell follicles. The transcript for Cyp $7 b 1$, the enzyme that can metabolize both $25-\mathrm{HC}$ and $27-\mathrm{HC}$ to the corresponding $7 \mathrm{a}$ EBI2 ligand, is instead more evenly distributed ${ }^{49}$. Such striking differences for the splenic pattern of Ch25h and Cyp27a1 suggest that, although both act on EBI2, $7 \alpha, 25-\mathrm{HC}$ and $7 \alpha, 27-\mathrm{HC}$ might be sensed by distinct cells: why multiple EBI2 ligands exist and what their functional implications are in vivo are not fully understood.

\section{Cholesterol biosynthetic intermediates as ROR $\gamma \mathrm{t}$ ligands}

Oxysterols, including $25-\mathrm{HC}$, have been initially identified as RAR-related orphan receptor gamma $\mathrm{t}(\mathrm{ROR} \gamma \mathrm{t})$ activators in biochemical assays ${ }^{50}$. ROR $\gamma t$ is an orphan nuclear receptor that 
is critical for lymphoid tissue organogenesis, T helper 17 (Th17) cells, and innate lymphoid cell group 3: digoxin was identified as an ROR $\gamma t$ antagonist on the basis of its ability to displace 25-HC binding to ROR $\gamma^{51}$. However, mice lacking 25-HC production did not show decreased IL-17 response or impaired lymphoid organogenesis, ruling out $25-\mathrm{HC}$ as an ROR $\gamma$ t activator in vivo. Two other oxysterols-7b,27-HC and 7a,27-HC - have also been suggested to be natural ligands for ROR $\gamma t^{52}$, and mice deficient in the enzyme Cyp27a1 indeed showed reduced IL-17-producing cells. Such reduction was observed only in young animals, and Cyp27a1-deficient mice were not protected during IL-17-dependent immune disease models, suggesting that other ROR $\gamma$ t ligands-endogenous or exogenous or both-might exist.

More recently, ROR $\gamma t$ ligand was mapped as a cholesterol biosynthetic intermediate (CBI) by an insect cell-based ROR $\gamma t$ reporter system $^{53}$. Deficiency in two enzymes involved in CBI resulted in distinct phenotypes for ROR $\gamma t+$ cells: lack of Cyp51 showed smaller lymph node anlagen in embryo at E14.5, while $\mathrm{T}$ cell-restricted Sc4mol deficiency led to partial reduction of in vitro Th17 cells but had no impact on lymph node development. Such partial and cell-specific phenotypes suggest that multiple ligands could regulate ROR $\gamma$ t function in vivo and specific CBI might act as an ROR $\gamma t$ ligand in distinct cells.

More studies are needed to fully capture the in vivo production of cholesterol metabolites and their source and their effect on immune cells. Only the systematic combination of enzymatic deficiency and receptor deficiency in vivo will allow us to dissect the role of the cholesterol metabolite in the maintenance, regulation, and activation of both innate and adaptive immune systems.

\section{Grant information}

This work was supported by the Jane Coffin Child's Memorial Fellowship (EVD), the Kenneth Rainin Foundation (AR), and the Charles H. Hood Foundation (AR).

The funders had no role in study design, data collection and analysis, decision to publish, or preparation of the manuscript.
1. Ikonen E: Cellular cholesterol trafficking and compartmentalization. Nat Rev Mol Cell Biol. 2008; 9(2): 125-138.

PubMed Abstract | Publisher Full Text

2. Mutemberezi V, Guillemot-Legris O, Muccioli GG: Oxysterols: From cholesterol metabolites to key mediators. Prog Lipid Res. 2016; 64: 152-169.

PubMed Abstract | Publisher Full Text

3. Russell DW: The enzymes, regulation, and genetics of bile acid synthesis. Annu Rev Biochem. 2003; 72: 137-174.

PubMed Abstract | Publisher Full Text

4. Payne AH, Hales DB: Overview of steroidogenic enzymes in the pathway from cholesterol to active steroid hormones. Endocr Rev. 2004; 25(6): 947-970. PubMed Abstract | Publisher Full Text

5. Goldstein JL, DeBose-Boyd RA, Brown MS: Protein sensors for membrane sterols. Cell. 2006; 124(1): 35-46. PubMed Abstract | Publisher Full Text

6. Horton JD, Shah NA, Warrington JA, et al:: Combined analysis of oligonucleotide microarray data from transgenic and knockout mice identifies direct SREBP target genes. Proc Natl Acad Sci U S A. 2003; 100(21): 12027-12032. PubMed Abstract | Publisher Full Text | Free Full Text

7. Gong Y, Lee JN, Lee PC, et al:: Sterol-regulated ubiquitination and degradation of Insig-1 creates a convergent mechanism for feedback control of cholesterol synthesis and uptake. Cell Metab. 2006; 3(1): 15-24. PubMed Abstract | Publisher Full Text

8. Motamed M, Zhang Y, Wang ML, et al.: Identification of luminal Loop 1 of Scap protein as the sterol sensor that maintains cholesterol homeostasis. J Biol Chem. 2011; 286(20): 18002-18012.

PubMed Abstract | Publisher Full Text | Free Full Text

9. Adams CM, Reitz J, De Brabander JK, et al.: Cholesterol and 25hydroxycholesterol inhibit activation of SREBPs by different mechanisms, both involving SCAP and Insigs. J Biol Chem. 2004; 279(50): 52772-52780. PubMed Abstract | Publisher Full Text

10. Sakai J, Duncan EA, Rawson RB, et al:: Sterol-regulated release of SREBP-2 from cell membranes requires two sequential cleavages, one within a transmembrane segment. Cell. 1996; 85(7): 1037-1046. PubMed Abstract | Publisher Full Text

11. Horton JD, Goldstein JL, Brown MS: SREBPs: activators of the complete program of cholesterol and fatty acid synthesis in the liver. J Clin Invest. 2002; 109(9): 1125-1131.

PubMed Abstract | Publisher Full Text | Free Full Text

12. Heiniger HJ, Marshall JD: Cholesterol synthesis in polyclonally activated cytotoxic lymphocytes and its requirement for differentiation and proliferation. Proc Natl Acad Sci U S A. 1982; 79(12): 3823-3827. PubMed Abstract | Publisher Full Text | Free Full Text
13. F Blanc M, Hsieh WY, Robertson KA, et al:: The transcription factor STAT-1 couples macrophage synthesis of 25-hydroxycholesterol to the interferon antiviral response. Immunity. 2012; 38(1): 106-18. PubMed Abstract | Publisher Full Text | Free Full Text | F1000 Recommendation

14. Liu SY, Aliyari R, Chikere K, et al.: Interferon-inducible cholesterol25-hydroxylase broadly inhibits viral entry by production of 25-hydroxycholesterol. Immunity. 2012; 38(1): 92-105. PubMed Abstract | Publisher Full Text | Free Full Text

15. F York AG, Williams KJ, Argus JP, et al.: Limiting Cholesterol Biosynthetic Flux Spontaneously Engages Type I IFN Signaling. Cell. 2015; 163(7): 1716-1729. PubMed Abstract | Publisher Full Text | Free Full Text | F1000 Recommendation

16. F Robertson KA, Hsieh WY, Forster T, et al:: An Interferon Regulated MicroRNA Provides Broad Cell-Intrinsic Antiviral Immunity through Multihit Host-Directed Targeting of the Sterol Pathway. PLOS Biol. 2016; 14(3): e1002364.

PubMed Abstract | Publisher Full Text | Free Full Text | F1000 Recommendation

17. Reboldi A, Dang EV, McDonald JG, et al.: Inflammation. 25-Hydroxycholesterol suppresses interleukin-1-driven inflammation downstream of type I interferon. Science. 2014; 345(6197): 679-684.

PubMed Abstract | Publisher Full Text | Free Full Text

18. F Broz P, Dixit VM: Inflammasomes: mechanism of assembly, regulation and signalling. Nat Rev Immunol. 2016; 16(7): 407-420. PubMed Abstract | Publisher Full Text | F1000 Recommendation

19. F Dang EV, McDonald JG, Russell DW, et al:: Oxysterol Restraint of Cholesterol Synthesis Prevents AIM2 Inflammasome Activation. Cell. 2017; 171(5): 1057-1071.e11. PubMed Abstract | Publisher Full Text | Free Full Text | F1000 Recommendation

20. F Westerterp M, Gautier EL, Ganda A, et al:: Cholesterol Accumulation in Dendritic Cells Links the Inflammasome to Acquired Immunity. Cell Metab. 2017; 25(6): 1294-1304.e6.

PubMed Abstract | Publisher Full Text | Free Full Text | F1000 Recommendation

21. F Joseph SB, Castrillo A, Laffitte BA, et al:: Reciprocal regulation of inflammation and lipid metabolism by liver $\mathbf{X}$ receptors. Nat Med. 2003; 9(2): 213-219. PubMed Abstract | Publisher Full Text | F1000 Recommendation

22. Ghisletti S, Huang W, Ogawa S, et al.: Parallel SUMOylation-dependent pathways mediate gene- and signal-specific transrepression by LXRs and PPARgamma. Mol Cell. 2007; 25(1): 57-70. PubMed Abstract | Publisher Full Text | Free Full Text

23. F Huang W, Ghisletti S, Saijo K, et al:: Coronin 2A mediates actin-dependent de-repression of inflammatory response genes. Nature. 2011; 470(7334): 
414-418.

PubMed Abstract | Publisher Full Text | Free Full Text | F1000 Recommendation

24. $F$ Ito A, Hong $C$, Rong $X$, et al:: LXRs link metabolism to inflammation through Abca1-dependent regulation of membrane composition and TLR signaling. eLife. 2015; 4: e08009.

PubMed Abstract | Publisher Full Text | Free Full Text | F1000 Recommendation

25. F Rong X, Albert CJ, Hong C, et al.: LXRs regulate ER stress and inflammation through dynamic modulation of membrane phospholipid composition. Cell Metab. 2013; 18(5): 685-697.

PubMed Abstract | Publisher Full Text | Free Full Text | F1000 Recommendation

26. Joseph SB, Bradley MN, Castrillo A, et al.: LXR-dependent gene expression is important for macrophage survival and the innate immune response. Cell. 2004; 119(2): 299-309.

PubMed Abstract | Publisher Full Text

27. F A-Gonzalez N, Guillen JA, Gallardo G, et al:: The nuclear receptor LXR $\alpha$ controls the functional specialization of splenic macrophages. Nat Immunol. 2013; 14(8): 831-839

PubMed Abstract | Publisher Full Text | Free Full Text | F1000 Recommendation

28. Kabouridis PS: Lipid rafts in T cell receptor signalling (Review). Mol Membr Biol. 2006; 23(1): 49-57.

PubMed Abstract | Publisher Full Text | Free Full Text

29. Gupta N, DeFranco AL: Lipid rafts and B cell signaling. Semin Cell Dev Biol. 2007; 18(5): 616-626.

PubMed Abstract | Publisher Full Text | Free Full Text

30. $F$ Yang $W$, Bai $Y, X$ Xong $Y$, et al.: Potentiating the antitumour response of $\mathrm{CD}^{+} \mathrm{T}$ cells by modulating cholesterol metabolism. Nature. 2016; 531(7596): 651-655.

PubMed Abstract | Publisher Full Text | Free Full Text | F1000 Recommendation

31. F Wang F, Beck-García K, Zorzin C, et al.: Inhibition of T cell receptor signaling by cholesterol sulfate, a naturally occurring derivative of membrane cholesterol. Nat Immunol. 2016; 17(7): 844-850.

PubMed Abstract | Publisher Full Text | Free Full Text | F1000 Recommendation

32. Pearce EL, Pearce EJ: Metabolic pathways in immune cell activation and quiescence. Immunity. 2013; 38(4): 633-643.

PubMed Abstract | Publisher Full Text | Free Full Text

33. Chakrabarti R, Engleman EG: Interrelationships between mevalonate metabolism and the mitogenic signaling pathway in T lymphocyte proliferation. J Biol Chem. 1991; 266(19): 12216-12222. PubMed Abstract

34. F Shimabukuro-Vornhagen A, Zoghi S, Liebig TM, et al:: Inhibition of protein geranylgeranylation specifically interferes with CD40-dependent B cell activation, resulting in a reduced capacity to induce T cell immunity. $J$ Immunol. activation, resulting in a PubMed Abstract | Publisher Full Text | F1000 Recommendation

35. F Bensinger SJ, Bradley MN, Joseph SB, et al.: LXR signaling couples stero metabolism to proliferation in the acquired immune response. Cell. 2008 134(1): 97-111.

PubMed Abstract | Publisher Full Text | Free Full Text | F1000 Recommendation

36. F Kidani $Y$, Elsaesser $\mathrm{H}$, Hock MB, et al:: Sterol regulatory element-binding proteins are essential for the metabolic programming of effector $\mathrm{T}$ cells and adaptive immunity. Nat Immunol. 2013; 14(5): 489-99.

PubMed Abstract | Publisher Full Text | Free Full Text | F1000 Recommendation

37. Cyster JG, Dang EV, Reboldi A, et al.: 25-Hydroxycholesterols in innate and adaptive immunity. Nat Rev Immunol. 2014; 14(11): 731-743. PubMed Abstract | Publisher Full Text

38. $\mathrm{F}$ Hannedouche $\mathrm{S}$, Zhang $\mathrm{J}, \mathrm{Yi} \mathrm{T}$, et al: Oxysterols direct immune cell migration via EBI2. Nature. 2011; 475(7357): 524-527. PubMed Abstract | Publisher Full Text | Free Full Text | F1000 Recommendation
39. Kelly LM, Pereira JP, Yi T, et al.: EBI2 guides serial movements of activated B cells and ligand activity is detectable in lymphoid and nonlymphoid tissues. $J$ Immunol. 2011; 187(6): 3026-3032.

PubMed Abstract | Publisher Full Text | Free Full Text

40. F Pereira JP, Kelly LM, Xu Y, et al.: EBI2 mediates B cell segregation between the outer and centre follicle. Nature. 2009; 460(7259): 1122-1126. PubMed Abstract | Publisher Full Text | Free Full Text | F1000 Recommendation

41. Gatto D, Paus D, Basten A, et al:: Guidance of B cells by the orphan G proteincoupled receptor EBI2 shapes humoral immune responses. Immunity. 2009; 31(2): 259-269.

PubMed Abstract | Publisher Full Text

42. $\mathrm{F}$ Yi T, Wang X, Kelly LM, et al.: Oxysterol gradient generation by lymphoid stromal cells guides activated $B$ cell movement during humoral responses. Immunity. 2012; 37(3): 535-548.

PubMed Abstract | Publisher Full Text | Free Full Text | F1000 Recommendation

43. F Suan D, Nguyen A, Moran I, et al.: T follicular helper cells have distinct modes of migration and molecular signatures in naive and memory immune responses. Immunity. 2015; 42(4): 704-718.

PubMed Abstract | Publisher Full Text | F1000 Recommendation

44. F $\mathrm{Li}$ J, Lu E, Yi T, et al.: EBI2 augments Tfh cell fate by promoting interaction with IL-2-quenching dendritic cells. Nature. 2016; 533(7601): 110-114. PubMed Abstract | Publisher Full Text | Free Full Text | F1000 Recommendation

45. F Emgård J, Kammoun H, García-Cassani B, et al.: Oxysterol Sensing through the Receptor GPR183 Promotes the Lymphoid-Tissue-Inducing Function of Innate Lymphoid Cells and Colonic Inflammation. Immunity. 2018; 48(1): 120-132.e8.

PubMed Abstract | Publisher Full Text | Free Full Text | F1000 Recommendation

46. F Chu C, Moriyama S, Li Z, et al:: Anti-microbial Functions of Group 3 Innate Lymphoid Cells in Gut-Associated Lymphoid Tissues Are Regulated by G-Protein-Coupled Receptor 183. Cell Rep. 2018; 23(13): 3750-3758. PubMed Abstract | Publisher Full Text | F1000 Recommendation

47. Gatto D, Wood K, Caminschi I, et al:: The chemotactic receptor EBI2 regulates the homeostasis, localization and immunological function of splenic dendritic cells. Nat Immunol. 2013; 14(5): 446-453. PubMed Abstract | Publisher Full Text

48. Yi T, Cyster JG: EBI2-mediated bridging channel positioning supports splenic dendritic cell homeostasis and particulate antigen capture. eLife. 2013; 2 e00757.

PubMed Abstract | Publisher Full Text | Free Full Text

49. Lu E, Dang EV, McDonald JG, et al: Distinct oxysterol requirements for positioning naïve and activated dendritic cells in the spleen. Sci Immunol. 2017; 2(10): pii: eaal5237.

PubMed Abstract | Publisher Full Text | Free Full Text

50. Jin L, Martynowski D, Zheng S, et al: Structural basis for hydroxycholesterols as natural ligands of orphan nuclear receptor RORgamma. Mol Endocrinol. 2010; 24(5): 923-929.

PubMed Abstract | Publisher Full Text | Free Full Text

51. $\quad F$ Huh JR, Leung MW, Huang $P$, et al.: Digoxin and its derivatives suppress $T_{H} 17$ cell differentiation by antagonizing ROR $\gamma t$ activity. Nature. 2011 472(7344): 486-490.

PubMed Abstract | Publisher Full Text | Free Full Text | F1000 Recommendation

52. $\mathrm{F}$ Soroosh $\mathrm{P}, \mathrm{Wu} \mathrm{J}, \mathrm{Xue} \mathrm{X}$, et al:: Oxysterols are agonist ligands of ROR $\gamma \mathbf{t}$ and drive Th17 cell differentiation. Proc Natl Acad Sci U S A. 2014; 111(33): 12163-12168.

PubMed Abstract | Publisher Full Text | Free Full Text | F1000 Recommendation

53. F Santori FR, Huang P, van de Pavert SA, et al.: Identification of natural ROR $\gamma$ ligands that regulate the development of lymphoid cells. Cell Metab. 2015; 21(2): 286-298.

PubMed Abstract | Publisher Full Text | Free Full Text | F1000 Recommendation 


\section{Open Peer Review}

\section{Current Peer Review Status:}

\section{Editorial Note on the Review Process}

Faculty Reviews are review articles written by the prestigious Members of Faculty Opinions. The articles are commissioned and peer reviewed before publication to ensure that the final, published version is comprehensive and accessible. The reviewers who approved the final version are listed with their names and affiliations.

\section{The reviewers who approved this article are:}

\section{Version 1}

\section{Michael Fessler}

Immunity, Inflammation, and Disease Laboratory, National Institute of Environmental Health Sciences, National Institutes of Health, Research Triangle Park, NC, USA

Competing Interests: No competing interests were disclosed.

\section{John Chiang}

Department of Integrative Medical Sciences, Northeast Ohio Medical University, Rootstown, OH, USA

Competing Interests: No competing interests were disclosed.

The benefits of publishing with F1000Research:

- Your article is published within days, with no editorial bias

- You can publish traditional articles, null/negative results, case reports, data notes and more

- The peer review process is transparent and collaborative

- Your article is indexed in PubMed after passing peer review

- Dedicated customer support at every stage

For pre-submission enquiries, contact research@f1000.com 